\title{
Teaching Material Mathematics with a Metacognitive Approach Guidance
}

\author{
Arvyaty, Salim*, Era Maryanti \\ Department of Mathematics Education, Halu Oleo University, Indonesia
}

\begin{tabular}{l} 
Article Info \\
\hline Article history: \\
Received Oct 13, 2017 \\
Revised Feb 22, 2018 \\
Accepted Apr 22, 2018 \\
\hline
\end{tabular}

Keywords:

Mathematical literacy

Metacognitive guidance

Teaching material

\begin{abstract}
The purpose of this research is to analyze the improvement of students' mathematical literacy ability through the use of mathematics teaching materials with metacognitive approach guidance. This research will be held in the city of Kendari to the subject of this research target is students who are at grade 5 Land in Junior High VIIID Kendari years lessons 2017/2018 with many limited scale trial class is only required as much as 1 class. To know the significance of the increase in the literacy abilities of students using paired t-test. Data processing using the SPSS program with criteria if $\alpha=0,05$ then there is an increased of student's mathematical literacy ability. The results of the analysis on the stages of the evaluation shows the learning materials with metacognitive approach guidance can provide better against an increase in student learning. The ability of the early mathematical literacy against students is very less because of learning during this time students have not been directed with the ability of mathematical literacy. After the students get learning by using learning materials through metacognitive approach guidance, the ability of mathematical literacy students' level 3 and level 4 underwent significant improvement.
\end{abstract}

Copyright $\odot 2018$ Institute of Advanced Engineering and Science. All rights reserved.

\section{Corresponding Author:}

Salim,

Departement of Mathematics Education,

Halu Oleo University,

Kampus Hijau Bumi Tridharma Andounohu Kendari 93232, Indonesia.

Email: salimpsa@gmail.com

\section{INTRODUCTION}

The results of the PISA study of weak ability of students lies in the ability to answer the question of level 5 and 6, which means that students are not able to interpret mathematical abilities in everyday life in a variety of contexts. However, it does also occur in Junior High School students with low ability of Kendari mathematical literacy in answering a question of starting at level 3 and level 4, level 5 and level 6. Another possible cause is the students are less accustomed to the process of solving connection correctly, i.e. with the stages of understanding the problem-solving, planning, implementing and troubleshooting check the results breakdown problem.

With respect to the above problem is related with the process of student Metacognition is a complex skill that takes long enough to be owned by students so that the necessary effort gradually have these skills. Nevertheless it can be started from teachers using special learning approaches that are specifically able to train students. One approach to learning that is quite relevant metacognitive approach guidance is used

Metacognitive approach guidance was first introduced by Kramarski [1] is a learning approach to train students to be able to have metacognition skills. This approach is based on the approach to IMPROVE the Mavrech and initiated by Kramarski [2]. In the method of IMPROVE there are three important components, namely: metacognitive questioning, cooperative learning, and the provision of systematic 
feedback-corrective-'s. Based on the method of improving metacognitive approach, then the guidance gave rise to four levels of questions, namely:

a. The comprehension questions, which are designed to encourage students in imagine or think of tasks or questions before solved.

b. The connection questions, to encourage students to focus on the similarities or difference of duties/job they do now with the tasks/jobs that already they used to do before.

c. The strategic questions designed, to prompt students to consider the proper strategies in completing a given task or problem and what can be given.

d. The reflection questions designed, to encourage the students reflect on their intuition and understanding during the process was underway.

Metacognitive approach guidance, want to students are taught how to interpret a problem so that it is capable of describing mathematical problem with their own language so that it is able to solve the problem, and in the end the students literacy abilities can be realized. Kramarski [3] has argued that "Mathematical literacy" is used here to indicate the ability to put mathematical knowledge and skills to use rather than just mastering them within a school curriculum. To "engage in" mathematics covers not just a simple calculation (such as deciding how much change to give someone in a shop) but also wider uses, including taking a point of view and appreciating things expressed numerically (such as having an opinion about a government's spending plan). Mathematical literacy is assessed by giving students' tasks based on situations which represent the kind of problems encountered in real-life.

Mathematical literacy is the ability of a person to formulate, interpret and use mathematics in various contexts of everyday life problems efficiently. Mathematics is meant to cover the whole concept, procedure, fact and mathematical tools from either side of the calculation, numbers or keruangan. In terms of process, this ability is not only limited to the ability to calculate only but also how to communicate, reasoning and other mathematical thought processes. Those processes embodied in the process matematisasi [4]

This approach is actualized in student learning activities through the construction of teaching materials to improve students' mathematisl literacy ability. Sanjaya [5] suggests that teaching material is anything that becomes the content of the curriculum that must be mastered by students in accordance with basic competencies in order to achieve the competency standards of each subject in a particular education unit. According to Winkel [6] extended learning materials are materials used for learning and help to achieve the goal of instructional. Hamalik [7] suggests that learning materials are an important part in the process of teaching and learning that occupies the position in determining the success of teaching and learning related to the learning objectives and determining ketercapaian teaching and learning activities. Therefore, teaching materials need to get consideration carefully. The existence of the learning materials learning more effective, then the teacher will have plenty of time to guide students in understanding a topic of study.

Based on the above description, the purpose of this research is to analyze the improvement of students' mathematical literacy ability through the use of mathematics teaching materials with metacognitive approach guidance.

\section{RESEARCH METHOD}

This research uses quasi experiment approach with the design of one group pretest-posttest design. Experimental group were given reserved tests before and after the implementation of learning. The design of this research can be described in Table 1.

Table 1. One Group Pretest-Posttest Design

\begin{tabular}{cccc}
\hline Class & Observation & Treatment & Observation \\
\hline Experiment & $\mathrm{O}_{1}$ & $\mathrm{X}_{1}$ & $\mathrm{O}_{2}$ \\
\hline
\end{tabular}

This research will be held in the city of Kendari to the subject of this research target is students who are at grade 5 Land in Junior High VIIID Kendari years lessons 2017/2018 with many limited scale trial class is only required as much as 1 class.Analysis of improvement of literacy ability calculated using paired t-testtest with the following formula [8]:

$$
t=\frac{M_{d}}{\sqrt{\frac{\sum x_{d}^{2}}{n(n-1)}}}
$$


Increased ability of mathematical literacy students are also presented in the form of diagrams and to know the significance of the increase in the literacy abilities of students using paired t-test. Data processing using the SPSS program criteria reject Ho, if the value of smaller significance of $\alpha=0.05$, and receive Ho, if the value of the larger significance of $\alpha=0.05$. Thus the smaller the $\alpha=0.05$ indicates that there is a significant improvement against the ability of mathematical literacy of students.

\section{RESULTS AND ANALYSIS}

Preparation of learning materials is designed based on the results of a preliminary study based on the results of the analysis of the needs of the development of learning materials which are obtained from the perceptions of teachers and students, the study of theoretical and practical, and curriculum. Learning materials developed have characteristics, i.e. load the stages of guidance, metacognitive approach to presenting content material contains mathematical literacy level 3 and level 4, and experiential learning curriculum learning charge corresponding to 2013

The need of developing learning materials for this event will be based by a few things. First, the learning materials used Junior High School mathematics teacher 5 Kendari class VIII in the learning process depends on book packages provided in bookshops and sometimes less in accordance with the product of learning which should be obtained by the students. Math teachers also do not develop mathematical materials for the purposes of supporting learning in the class. Second, students at the secondary grade VIII has entered the stage of formal operations resulting in learning math students can already trained its ability to think abstractly, logical, common sense and draw conclusions from the information available. But this condition is inversely proportional to the ability of the students in the Junior High School 5 Kendari. Currently, the ability is not applied properly. Students sometimes can't afford to apply the mathematics they can to solve the problems they encounter in other sciences as well as in everyday life.

Third, the results of student achievement age 15 years (equivalent to grade VIII Junior High School) in Indonesia are likely to still lower based on OECD data in any content that is to be tested in the study gained an average of PISA students Indonesia ranked two levels down. This suggests that mathematical literacy of students in Indonesia only to the reproductive capabilities, i.e. the ability of mathematical pengopresian in a simple context [9]. Low literacy students located on a weak ability to answer the question of literacy level 3 to level 6, meaning students were not able to interpret of mathematical ability in daily life in a variety of contexts. This condition also occurs in students of Junior High School 5 Kendariin the country literacy students with the capabilities of Palangkaraya averaged only are still at level 1 and level 2, learning math in the classroom have not lead students on mathematical literacy, learning ability done to achieve the target regardless of curriculum trends and demands of the times.

Fourth, the implementation of the curriculum in Junior High School 5 Kendari materializes on the results of the implementation of the learning of mathematics in the classroom showing the ssiwa haven't been able to develop his thinking ability in maximum, the learning process has not made the students have the habit of reading while thinking and work, on the settlement of the question of who carried out the students who seemed mechatisticmasic doses too large a dose, and reasoning are still low, students are less accustomed to make the process connection in problem solving correctly. Therefore, this condition certainly needs to make changes to the mindset of students through an approach of learning, i.e. approaches that train student's thought, consciousness so that they can perform specific tasks and can then use the consciousness to control what students are working on. The approach in question is a metacognitive approach guidance based on the self questioning so that with this approach, students can interpret a problem, describe the problem with its own language, and solve a problem with ease.

The need of developing learning materials above gave rise to a characteristic of the materials. First, load the stages of guidance metacognitive approach with coverage of the four levels of questions that have to be met in the learning materials include:

a. The comprehension questions, which are designed to encourage students in the imagined or thought about these questions or tasks before solved (statement: what is known and asked).

b. The connection question, designed to encourage students to focus on the similarities or difference of duties they do now with the tasks that already they did before (the statement: If a given problem, there is a something to do with the concept of learned or other equivalent concepts? How do you know? Explain)

c. The strategic questions, designed to prompt students to consider the proper strategies in completing a given task or problem and what can be given (the statement: If you think these concepts can help you solving certain, strategies/tactics/principles are that you can use to count them)

d. The reflection questions, designed to encourage the students reflect on their understanding and intuition for that process to take place (the statement: write the process of your calculation and please check back the truth in your calculation, as well as corrections if there is the wrong process). 
Second, the presentation of the content material contains mathematical literacy level 3 and level 4. In the presentation of the content material ranging from example problems, student activities, exercises, and competence form the problem leads to mathematical literacy level 3 and level 4. Mathematical literacy level 3 i.e. the ability of the students to be able to carry out the procedure, including the procedure requiring decisions in sequence. Students can select and apply problem-solving strategies are simple. While the mathematical literacy level 4 students ' ability to work effectively with models and concrete context, the ability to select and integrate all types of representation and observe the dependencies in real life.

Third, the charge in accordance with the learning experience learning curriculum is 2013. Charge the student learning experience on the learning materials will be developed covering material class VIII Junior High School semester i.e. systems of linear equations in two variables, quadratic equations, circular, flat-side wake, comparison and opportunities. This material must have corresponding to the 2013 curriculum study on charge applicable to the Junior High School in the town of Kendari.

The capacity analysis of mathematical literacy students shows there is an increase in the ability of mathematical literacy students score well on level 3 or level 4 . The results of the analysis are presented in Figure 1 below.

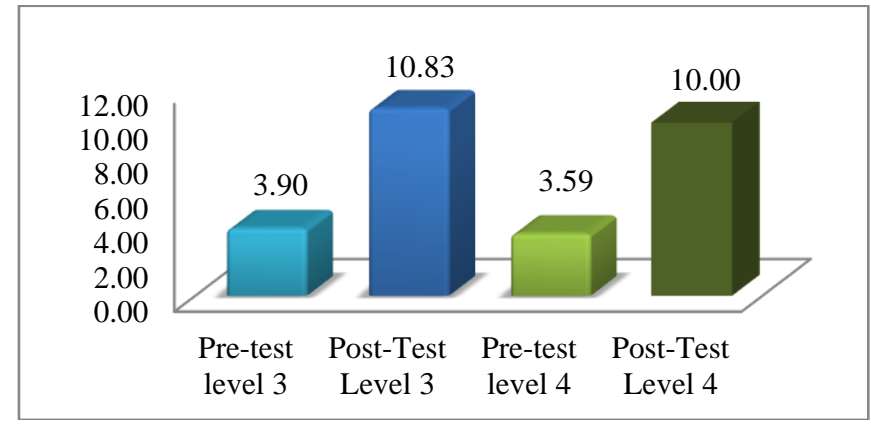

Figure 1. Improvement of mathematical literacy of students

The average increase in the ability of mathematical literacy level 3 students amounted to 6,93 and an average increase in mathematical literacy level 4 students of 6,41 . To see the significance of increasing the ability of mathematical literacy test used paired t-test with data analysis using SPSS program with the help of the results show there is a fairly significant improvement against literacy abilities mathematical students at level 3 and level 4. A recap of the results of statistical tests presented in table 2 below.

Table 2. Test of Mathematical Literacy Ability Improvement

\begin{tabular}{ccc}
\hline Literacy Ability & Average & Sig. \\
\hline Level 3 & 6,93 & 0,000 \\
Level 4 & 6,41 & 0,000 \\
\hline
\end{tabular}

The results of the analysis on the stages of the evaluation shows the learning materials with metacognitive approach guidance can provide better against an increase in student learning. The ability of the early mathematical literacy against students is very less because of learning during this time students have not been directed with the ability of mathematical literacy. After the students get learning by using learning materials through metacognitive approach guidance, the ability of mathematical literacy students level 3 and level 4 underwent significant improvement.

The results of this increase are inseparable from the content that is present on the materials. Students are not just reading the material and example problem that exists, but content learning materials designed for students engage directly resolve the problem that has been provided. Metacognition questions contained in the resolution of a matter of helping students find the concept itself and generate a broader understanding. This is in line with the results of research conducted [9] that students who have good Metacognition abilities tend to be able to solve the problem that was faced with either through the deployment of consciousness and thinking the setting He did.

Junior High School math class VIII learning by using learning materials through metacognitive approach guidance makes the students began to realize that math is not being a rigid learning, required only 
memorizing formulas, but start students to be able to use some of the concepts in mathematics to solve everyday life. In addition, with these materials, students can overcome the misconception of the material, reducing the confusion students in doing the calculations, giving an answer with the correct procedure.

\section{CONCLUSION}

Based on the results of this research it can be concluded that there is an increase in the ability of mathematical literacy students level 3 and level after getting the learning by using learning materials with a metacognitive approach guidance. A few suggestions that may be advanced as follows: (a) teaching materials with a metacognitive approach guidance should be used as one of the primary sources of learning to improve students mathematics literacy ability, (b) it takes a longer in the implementation of learning materials with metacognitive approach guidance with the aim of enabling the learning process to master ability in metacognition more maximum again so that students can have learning experiences are meaningful and intact.

\section{ACKNOWLEDGEMENTS}

With the full flavor of the sincerity of the author to present a thank you to the team of researchers that hard-fought selflessly in completing the research and credits we gave to the validator that have available time to evaluate the learning materials. The writer also says thanks a lot to the head of SMP Negeri 5 quandary that gave the opportunity and his dedication in limited trials on this research

\section{REFERENCES}

[1] B. Kramarski\& Mizarchi, "Enhancing Mathematical Literacy with The Use of Metacognitive Giudance in Forum Discussion,". Proceedings of the $28^{\text {th }}$ Conference of the International Group for the Psychology of MathematicsEducation, 2004.

[2] B. Kramarski and Z. Mevarech, "Cognitive - Metacognitive Training within a Problem Solving Based Logo Environment. British Journal of Educational Psychology,Vol. 67, pp. 425-445, 1997.

[3] B. Kramarski and Z. Mevarech. "Metacognitive Discourse in Mathematics Classrooms". In Journal European Research in Mathematics Education III (Thematic Group 8), 2004.

[4] Rosalia Hera Novita Sari, " Mathematical Literacy: What, Why and How?," National Seminar on Mathematics and Mathematics Education UNY, pp. 713-720, 2015.

[5] Wina Sanjaya, "Perencanaan Dan Desain Sistem Pembelajaran", Bandung : Prenata Media Group, 2008.

[6] WS Winkel, "Psikologi Pengajaran", Yogjakarta: Media Abadi, 2004.

[7] Umar Hamalik, "Perencanaan Pengajaran Berdasarkan Pendekatan Sistem,",Jakarta : Bumi Aksara, 2002.

[8] Supardi, "Application Of Statistics In Research (A More Comprehensive Statistical Concept), Jakarta: Change Publication, 2013.

[9] Mustamin Anggo, "Contextual Math Problem Solving To Improve The Ability Of Metacognition Of The Students," Edumatica Journal, Volume 01 Number 02, pp : 35-42, 2011. 